\title{
Dr. Roy Bakay and the Modern Era of Neurosurgical Mentorship
}

\author{
Philip A. Starr \\ Department of Neurological Surgery, University of California, San Francisco, Calif., USA
}

Roy Bakay, a mentor to many of us in functional neurosurgery, died on September 6, 2013 after several years of battling stomach cancer. Details of Roy's biography, along with personal anecdotes from his colleague and friend Jeff Kordower, were recently published in Movement Disorders [1]. I will not restate what has been eloquently written by others. Rather, as one of Roy's trainees, I will focus on his role as a mentor and how this mentorship has and will affect subsequent generations of neurosurgeons.

I was fortunate to be one of Roy's first fellows in functional neurosurgery from 1996 to 1998 when he was at Emory University. The fellowship was mentored jointly by Roy and three neurologists/neuroscientists: Mahlon DeLong, Jerrold Vitek, and Thomas Wichmann. It was one of the original truly interdisciplinary fellowships, presaging an era when advanced neurosurgical trainees in our subspecialty need mentors in neurology, neuroscience, psychiatry and engineering/neuroprosthetics as well as neurosurgery. At that time Emory was the 'Camelot' of movement disorders surgery: they had just established the first robust theoretical foundation for basal ganglia surgery in Parkinson's disease [2], launched the first large NIH-funded prospective study of pallidotomy [3], set a new standard of precision for the use of single-cell recording in neurosurgery [4], and helped to define the physiology and rational basis for basal ganglia surgery in primary dystonia [5]. In 1997, Emory was one of

\section{KARGER} www.karger.com/sfn
E-Mail karger@karger.com

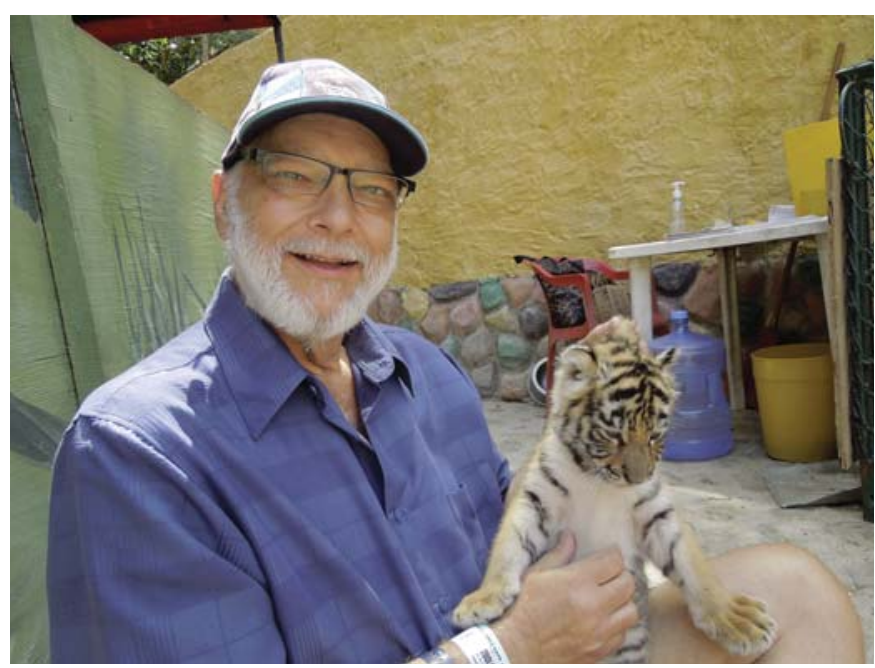

Dr. Roy Bakay

the first groups to introduce deep brain stimulation for movement disorders to the United States, after a period of close interaction with the European pioneers of this technique $[6,7]$. The fellowship launched my career but was simultaneously one of the most relaxed and fun times of my life, and I am grateful to Roy for this.
C 2014 S. Karger AG, Basel

1011-6125/14/0924-0201\$39.50/0 
At the University of California, San Francisco, I consider our functional neurosurgery fellows to be 'secondgeneration' Emory fellows, as our group has tried to replicate a number of core features of the Emory experience of the 1990s. Our fellows are jointly mentored by neurologists as well as neurosurgeons, and work in a multidisciplinary clinic that has all the elements required for comprehensive patient care. Likewise, movement disorders neurology fellows are trained, often by the neurosurgery fellow, to do stereotactic targeting, and they are invited into the operating room to learn intraoperative navigation. I learned from Roy to reject artificial barriers between disciplines. Our fellowship, like Roy's, is a departure from residency rather than a continuation of it - an academically rich time with no on-call responsibilities, generous unstructured time, and a choice of activities for the trainee. A major goal is to have the time to read, write, and to relax and enjoy life - a brief respite between the demands of residency and the high responsibly and academic pressures of a faculty position. Roy was generous with the space and free time he allowed his fellows.

Many styles of mentorship can be effective. Roy was reserved with many people and could be perceived as in- timidating. Yet once he got to know and like someone, he was extremely relaxed, funny, and fun-loving. If you 'hung in there' with Roy, he'd become your friend. Many of his best friends were colleagues in neurology and neuroscience, and he loved to dine, dance, ski, and scuba dive with those he was close to.

In March 2013, many of Roy's colleagues and trainees enjoyed a symposium in his honor in Chicago, where he practiced for the last decade. The symposium was organized by one of his former fellows, Sean O'Leary. Roy felt relatively well at that time and greatly enjoyed the event, which included a dinner and a number of talks on functional neurosurgery. Two of his children were there, as was his companion of the last few years, Cheryl Morris. Cheryl is a nurse who obviously loved Roy and very much helped him with his care, such that he was able to continue to work and do surgeries up until 1 month before his passing. To continue to be productive was very important to Roy, and Cheryl helped to make this possible for him. Our best tribute to Roy is to prioritize advanced neurosurgical education so as to pass our skills on to the next generation, remembering always that our time on Earth is short.

\section{References}

1 Kordower JH: In memoriam: Roy A.E. Bakay. Mov Disord 2013;28:1809-1810.

$\checkmark 2$ Bergman H, Wichmann T, DeLong MR: Reversal of experimental parkinsonism by lesions of the subthalamic nucleus. Science 1990;249:1436-1438.

-3 Vitek JL, Bakay RA, Freeman A, Evatt M, Green J, McDonald W, Haber M, Barnhart H, Wahlay N, Triche S, Mewes K, Chockkan V, Zhang JY, DeLong MR: Randomized trial of pallidotomy versus medical therapy for Parkinson's disease. Ann Neurol 2003;53:558-569.
4 Vitek JL, Bakay RA, Hashimoto T, Kaneoke Y, Mewes K, Zhang JY, Rye D, Starr P, Baron M, Turner R, DeLong MR: Microelectrode-guided pallidotomy: technical approach and its application in medically intractable Parkinson's disease. J Neurosurg 1998;88:1027-1043.

5 Vitek JL, Chockkan V, Zhang JY, Kaneoke Y, Evatt M, DeLong MR, Triche S, Mewes K, Hashimoto T, Bakay RA: Neuronal activity in the basal ganglia in patients with generalized dystonia and hemiballismus. Ann Neurol 1999;46:22-35.
Benabid AL, Pollak P, Gao D, Hoffmann D, Limousin P, Gay E, Payen I, Benazzouz A: Chronic electrical stimulation of the ventralis intermedius nucleus of the thalamus as a treatment of movement disorders. J Neurosurg 1996;84:203-214.

7 Limousin P, Pollak P, Benazzouz A, Hoffmann D, Le Bas JF, Broussolle E, Perret JE, Benabid AL: Effect of parkinsonian signs and symptoms of bilateral subthalamic nucleus stimulation. Lancet 1995;345:91-95. 